DOI: https://doi.org/10.34137/jilses.612112

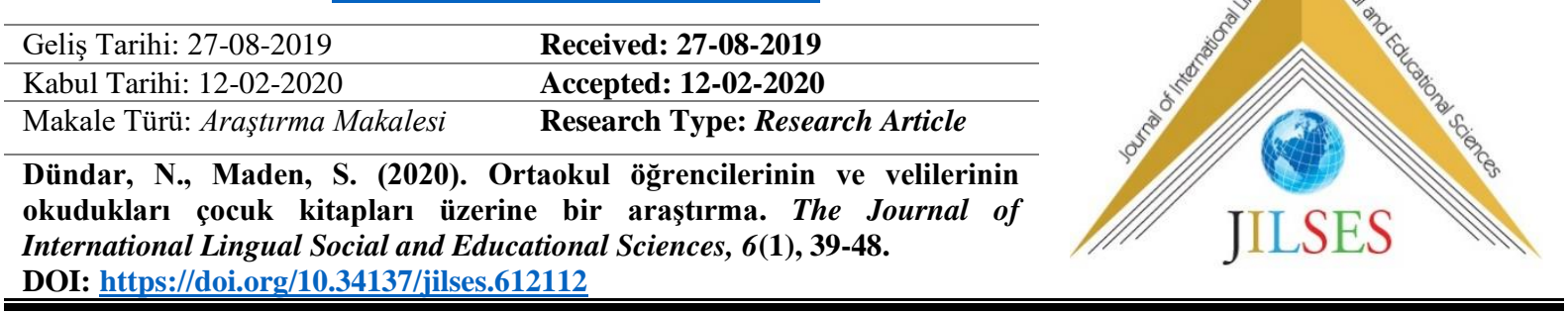

\title{
Ortaokul Öğrencilerinin ve Velilerinin Okudukları Çocuk Kitapları Üzerine Bir Araştırma * Nezaket DÜNDAR ${ }^{1}$ Sedat MADEN ${ }^{2}$
}

$\ddot{O} \mathbf{z}$

\begin{abstract}
Bu araştırmada, ortaokul öğrenci ve velilerinin okudukları çocuk kitaplarını tespit etmek amaçlanmıştır. Bu amaç doğrultusunda, velilerin çocuk kitaplarına yönelik bilgi düzeyleri ve bu eserleri ögrencileriyle birlikte okuma durumlarının belirlenmesi önemsenmiştir. Araştırma nitel araştırma desenlerinden fenomenolojiye göre yürütülmüşürr. 2017-2018 eğitim ögretim yll bahar döneminde yapılan araștırmanın evrenini Giresun ilinde ögrrenim görmekte olan 5, 6, 7 ve 8. sinıf ögrrenci velileri oluşturmaktadır. Araştırmanın örneklemini, Giresun il merkezinde yer alan Gedikkaya Ortaokulu ile Çavuşlu Ortaokulu'nda öğrenim gören 5, 6, 7 ve 8. sinı öğrenci velileri $(n=394)$ oluşturmuş olup velilerin okudukları edebiyat eserleri ile ögrencilerinin okudukları edebiyat eserleri arasındaki benzerlik ve farklılı̆̆ ortaya koymak amacıyla kolay ulaşılabilirlik açısından Çavuşlu Ortaokulu'ndaki ögrenciler $(n=80)$ de çalışmaya dâhil edilmiştir. Araştırmada veri toplama aracı olarak veli ve ögrencilere yönelik görüşme formları kullanılmıştır. Araştırmanın sonunda, velilerin en çok Keloğlan Masalları'nı, öğrencilerin ise Levent Serisi adlı kitapları okuduğu belirlenmiștir. Ayrıca velilerin çocuğunun okuduğu çocuk kitaplarından herhangi birini okumadığı, bununla beraber veliler ile diğer öğrencilerin okuduğu çocuk edebiyatı eserleri arasında 15 ortak kitabın olduğu sonuçlarına ulaşılmıştır.
\end{abstract}

Anahtar Sözcükler: Okuma, çocuk edebiyatı, kitap, ögrrenci, veli.

\section{A Study on Children Literature Works That Are Read}

\section{By Middle School Students and Parents}

\begin{abstract}
In this research, it was aimed to determine the literary works that secondary school students and parents read. Depending on this purpose, the level of knowledge of parents about children's books and the reading status of these works with their students are considered important. In the study, a qualitative research method was used. The universe of the study, which was conducted in the spring semester of 2017-2018 academic year, consists of parents of 5th, 6th, 7th and 8th grade students studying in Giresun province. The sample of the study was composed of parent's $(n=394)$ of the students in Gedikkaya Secondary School and Çavuşlu Secondary School in Giresun city. The students $(n=80)$ of Çavuşlu Middle School were also included in the study in terms of easy accessibility in order to reveal the similarities and differences between their works. In the research, student and parent interview forms were used as data collection tool. At the end of the study, it was determined that the parents read the Keloğlan Tales mostly and the students read the books Levent Series. It was also found that parents did not read any of the children's books read by their child. However, it has been concluded that there are 15 common books between parents and other students' works of children's literature.
\end{abstract}

Keywords: Reading, children's literature, book, student, parent.

\footnotetext{
* Bu makale, ikinci yazarın danışmanlığında birinci yazar tarafından hazırlanan yüksek lisans tezinden üretilmiştir.

${ }^{1}$ Türkçe Öğretmeni, Görele Çavuşlu Ortaokulu, Giresun. nez.gundogdu@ hotmail.com

${ }^{2}$ Doç. Dr. Giresun Üniversitesi, Eğitim Fakültesi, Türkçe Eğitimi Ana Bilim Dalı, sedat.maden@giresun.edu.tr https://orcid.org/0000-0002-8024-8182
} 


\section{Giriş}

İnsan doğar, büyür, çoğalır ve ölür. Bu süreçte insanlar bilgi birikimlerini, yaşantılarını, öğretilerini, kültürünü, sanatsal değerlerini neslini devam ettirecek olan çocuklarına aktarır. İnsanın öğrenme ve öğrendiğini uygulama açısından en hızlı olduğu dönem çocukluğudur (Şahin, 2007). Oysaki çocukluğun değeri ve önemi tüm dünyada yakın geçmişte fark edilmiş ve çocuğu önemseme, çocuğa bakış ve onunla ilgilenme eğilimleri de yakın geçmişten günümüze değişerek ulaşmıştır. Yine bu süreçte bilim insanları insanın çocukluğu döneminde oluşturduğu alt yapının daha sonraki yaşantılarına yön vereceğinden bahsetmişlerdir.

Çocukların fiziksel gelişiminin yanı sıra zihinsel gelişimleri de çok önemlidir. Ayrıca çocukların fiziksel ve zihinsel gelişimleri arasında bir etkileşim vardır. Yavuzer'e göre (2012: 27) “Çocuk sadece fiziksel olarak büyümekle kalmaz, aynı zamanda onun beyniyle iç organlarının yapı ve büyüklüğünde de değişmeler olur. Beynin gelişimi sonucu, çocukta giderek artan bir öğrenme, anımsama ve muhakeme yeteneği oluşur. Böylelikle fiziksel büyümeye koşut olarak, çocuk, zihinsel olarak da gelişir." Çocuğun zihinsel gelişiminde, okuma ve okuduğunu anlama becerilerinin kazanılmış olması gereklilik arz eder. Okuma yazmayı öğrenen bir çocuk hem okuma becerisini geliştirebilmek hem de anlama kabiliyetini desteklemek için zihinsel gelişimine uygun kitaplar okumalıdır. Bunun önemini Sever (2007: 17) "Çocuk, ilköğretime başlamasıyla birlikte, istekle kitap okumaya yönelir. Özellikle bu dönemde hem okuma yazma becerisinin gelişimine katkı sağlayacak hem de kendi (çocuk) gerçekliğine yanıt verebilecek kitaplara gereksinim duyar." şeklinde vurgulamıştır. Bu gereksinim çocuk edebiyatının önemini ortaya koymaktadır.

Çocuk edebiyatının çocuğun duygusal, düşünsel, zihinsel, dilsel ve estetik bakışı açısından gelişimindeki payını vurgulayan; çocuğun güzel, eğlenceli vakit geçirmesinde bir araç olma rolünü üstlendiğini ifade eden farklı birçok tanım yapılmıştır. Bu tanımlardan bazıları şöyledir: Sever'e göre (2007: 17) “Çocuk edebiyatı, ergenliğe kadar olan zaman diliminde çocukların hem sözel-dilsel zekâsını geliştiren hem de onlarda estetik zevk uyandıran ürünlerdir". Bu ürünler çocukların büyüme ve gelişmelerine, duygularına, hayallerine, düşüncelerine ve yeteneklerine katkıda bulunur ve onları eğitir, eğitirken de eğlendirir (Yalçın ve Aytaş, 2008). Gökşen (1980: 87) çocuk edebiyatını "çocuğun fikir ve sanat eğitimine katkıda bulunarak çocukta sanat duygusu ve üstünlüğü uyandıran, tekniği, ilkeleri olan, güzel ve etkili ürünlerden oluşan edebiyat" olarak tanımlamıştır. Bir başka tanıma göre ise "çocuk edebiyatı, çocukların büyüme ve gelişmelerine, hayal, duygu, düşünce ve duyarlılıklarına, zevklerine, eğitilirken eğlenmelerine katkıda bulunmak amacı ile gerçekleştirilen çocuksu bir edebiyattır" (Şirin, 2000: 9).

Çocuk edebiyatı ürünlerine neden ihtiyaç duyulduğu sorusunun cevabına yönelik bir açıklamayı Huck (1976: 21) "Çocuklar, küçük yetişkinler değil; kendi hakları, ilgileri ve yetenekleri olan bireylerdir. Bu anlayış, çocukluk dönemi ile ilgili merak, eğlence ve hayal kırıklığı duygularına hitap eden bir edebiyata ihtiyaç duyulduğu fikrini ortaya çıkarır" şeklinde yaparak çocuk dünyasının yetişkin dünyasından farklı olduğunu vurgulamış ve çocuklara yönelik bir edebiyatın kaçınılmaz olduğunu ifade etmiştir.

Çocuğa yönelik bir edebiyatın çocuğun anlayabileceği şekilde olması gerekir. "Çocuk edebiyatının dili, konusu, içeriği, anlatımı, yalınlığı ve içtenliğiyle önce çocuğa özgü olmasıdır. Çocuk edebiyatı ile edebiyat arasındaki ayrımın nedeni, çocuğun yetişkinden farklı algılama biçiminden kaynaklanır” (Şirin, 2007: 14). Çocuğun zaman içerisinde hayata dönük olumlu kazanımlara sahip olması, bir yaşam felsefesi geliştirebilmesinin bir aracı da çocuk edebiyatıdır. Alver'in (2005: 307) “Çocuğa edebiyatı sunmak, çocuğa dönük model oluşturma girişimidir. Hem onun nasıl bir insan olmasına dönük, hem de hayat tarzının hangi çizgide, çerçevede belirleneceğine ilişkin teklifleri yüklenmektir.” şeklindeki ifadeleri de bu görüşü destekler niteliktedir.

Aile, okuma alışkanlığının kazanımında önemli bir etkendir. Ailenin okumaya karşı tutumu, kültür seviyesi çocuğun okuma alışkanlığı üzerinde oldukça etkilidir. Okuma becerisi ve alışkanlığının kazanımında genellikle öğretmenler ön plana çıksa da bu konuda anne babalar da en az öğretmenler kadar önemlidir. Hatta anne babasının kitap okuduğunu gören, onlardan kitap hediye alan ve evinde kitaplık bulunan çocukların okuma alışkanlığının yüksek olduğu tespit edilmiştir (Suna, 2006). Bunların yanı sıra ailelerin birlikte kitap okuma etkinliği yapması, kitaplarla ilgili sohbet etmesi de okumanın alışkanlık kazanmasında etkili olacaktır (Savaş, 2006). Toplumun temelinde aile yer almaktadır. Aileler için de çocuklarının kültürel ve çağın gerektirdiği niteliklerle yetiştirilmesi öncelik taşır. Bu noktada çocukların bilişsel ve duyuşsal gelişimine, sosyalleşmesine yardımcı olacak kitapları seçip okumalarında ailenin rolü büyüktür. Anne babaların çocuk kitapları konusundaki yeterli farkındalığa ve okuma alışkanlığına sahip olmaları, okumaya yönelik tutumları çocuklarının okuma alışkanlığı kazanmalarında etkilidir. Ancak ülkemizdeki durum ile ilgili olarak Şahin, Çelik ve Çelik'in (2012: 111) "Çocuk edebiyatı ürünlerinin çocuklara ulaşması ancak veliler ve öğretmenler aracılığıyla olmaktadır; ancak velilerin ve öğretmenlerin yaş grupları ve kültür seviyelerine göre çocuklara hitap edecek olan yayınların seçiminde bilgili olmadıkları ve titiz davranmadıkları görülmektedir.” şeklindeki açıklamaları gerek veli gerekse öğretmen profili 
açısından istenilenden çok uzak olunduğunu ortaya koymaktadır. İstenilen seviyeye ulaşabilmek için anne babaların okudukları edebî eserleri veya çocuklarına uygun eserleri belirleyip önceden okuyup tavsiye etmeleri gerekir. Ayrıca Gürler'in (1999) konuyla ilgili araştırmasında, anne babaların çocuk kitapları konusunda bilgisiz oldukları ve bu durumun çocukların kitap edinmesine olumsuz etkide bulunduğu belirlenmiş̧tir. Bekar'ın (2005) çalışmasında da öğrencilerin okuma alışkanlığı kazanmasında ailelerin rolünün yeterli olmadığına dair tespitler yapılmıştır. Bunlara karşın Aksoy'un (2014) araştırmasında, velilerin çoğunluğunun okul öncesi dönemde çocuğunu kitaplarla ve okuma eylemiyle tanıştırdığı, velilerin yarısına yakınının çocuklarıyla beraberken kitap, gazete, dergi vb. yayınları okuduğu ve onlara bu şekilde model olduğu belirlenmiştir. Ailelerin çocukların okuma alışkanlığına etkisini belirlemeyi amaçlayan bu araştırmaların yanında velilerin çocuk edebiyatı eserlerine dair bilgisini ve öğrencilerle velilerin okudukları eserler arasındaki benzerlik ve farklılıkları ortaya koyan çalışmalara alanyazından ulaşılmamaktadır. Bu bağlamda, anne babaların okudukları çocuk edebiyatı eserlerinin belirlenmesi, çocuklarının da aynı eserleri okuyup okumadıklarının ortaya konulması var olan durumun netleşmesinde ve çözüm üretilebilmesinde fayda sağlayacaktır.

\section{Araştırmanın Amacı}

$\mathrm{Bu}$ araştırmada, ortaokul öğrenci ve velilerinin okudukları çocuk kitaplarının belirlenmesi amaçlanmaktadır. Bu amaç doğrultusunda aşağıdaki sorulara yanıt aranmıştır:

1. Velilerin okuduğu ve okumayıp hakkında bilgi sahibi olduğu çocuk edebiyatı eserleri hangileridir?

2. Hem velilerin hem de öğrencilerin okuduğu çocuk edebiyatı eserleri hangileridir?

\section{Yöntem}

Araştırmada nitel araştırma desenlerinden fenomenoloji (olgubilim) kullanılmıştır. Olgubilim araştırmalarında, bir olguyu daha iyi tanıma ve anlama ile insanların bu olguyla ilgili deneyimleri ve yaşantıları, bir grubun bu olguya yükledikleri anlamlar ortaya konmaya çalışılır (Yıldırım ve Şimşek, 2011).

\section{Örneklem}

Araştırmanın evrenini 2017-2018 Eğitim-Öğretim Yılı Bahar Döneminde Giresun ilinde öğrenim görmekte olan 5, 6, 7 ve 8. sınıf öğrenci velileri oluşturmaktadır. Araştırmanın örneklemini ise, Giresun il merkezinde yer alan Gedikkaya Ortaokulu ile Çavuşlu Ortaokulu'nda öğrenim gören 5, 6, 7 ve 8. sınıf öğrenci velileri $(\mathrm{n}=394)$ oluşturmuş olup velilerin okudukları edebiyat eserleri ile öğrencilerinin okudukları edebiyat eserleri arasındaki benzerlik ve farklılığı ortaya koymak amacıyla kolay ulaşılabilirlik açısından Çavuşlu Ortaokulu'ndaki öğrenciler $(\mathrm{n}=80)$ de çalışmaya dâhil edilmiştir.

\section{Verilerin Toplanması}

Çalışmada veri toplama aracı olarak, velilerin ve öğrencilerin okudukları çocuk edebiyatı eserleri ile hem velilerin hem de öğrencilerin okuduğu ortak eserleri ortaya koymak amacıyla "Çocuk Edebiyatına Yönelik Veli Görüşme Formu" ve "Okuma Alışkanlığına Yönelik Öğrenci Görüşme Formu" kullanılmıştır.

Çocuk Edebiyatına Yönelik Veli Görüşme Formu toplam 2 açık uçlu maddeden oluşmaktadır. Araştırmanın alt problemlerine uygun olarak veri toplamak amacıyla, açık uçlu maddelerden ilki çocuk kitaplarından varsa okunulan herhangi bir eserin yazılmasına, ikincisi ise çocuk kitaplarından okunmayıp isim olarak bilinen ya da duyulan eserlerin yazılmasına ilişkindir.

Okuma Allşkanlığına Yönelik Öğrenci Görüşme Formunda ise, öğrencilerine en son okuduğu eser ve yazarına ilişkin bir açık uçlu maddeye yer verilmiştir. Her iki görüşme formu geliştirilirken Türkçe eğitimi uzmanı $(\mathrm{n}=1)$ ve öğretmenlerinden $(n=2)$ kapsam geçerliğini sağlamak için görüş alınmış, açık uçlu maddelerde herhangi bir değişikliğe gidilmeksizin örnekleme uygulanmıştır. Veri toplama aracı olarak kullanılacak formlar gerekli izinler alındıktan sonra örnekleme elden ulaştırılarak toplanmıştır.

\section{Veri Analizi}

Araştırmada elde edilen veriler, araştırma amacı ve alt problemler doğrultusunda frekans $(f)$ ve yüzde (\%) değerleri kullanılarak çözümlenmiş; bulgular tablolar hâlinde sunulmuş ve yorumlanmıştır. 


\section{Bulgular}

\section{Velilerin Okuduğu ve Okumayıp Hakkında Bilgi Sahibi Olduğu Çocuk Kitaplarına Yönelik Bulgular}

Tablo 1: Velilerin okudukları ve bilgi sahibi oldukları çocuk kitaplarına yönelik bulgular

\begin{tabular}{ccc}
\hline & $\boldsymbol{f}$ & $\boldsymbol{\%}$ \\
\hline Okuyanlar & 187 & 47.6 \\
Okumayanlar & 207 & 52.5 \\
Eser Bilenler & 165 & 41.8 \\
Eser Bilmeyenler & 229 & 58.1 \\
\hline
\end{tabular}

Tablo 1'e bakıldığında, çocuk edebiyatı eseri okuyan veliler (\%47.6) ile okumayanlar (\%52.5) arasında çok büyük bir fark olmasa da çocuk kitabı okumayan velinin daha fazla olduğu görülmektedir. Yine tabloya göre çocuk edebiyatı eseri okumayıp bilgi sahibi olan velilerin oranının (\%41.8) eser bilmeyen velilerden (\%58.1) daha düşük olduğu görülmektedir.

Tablo 2: Velilerin okuduğu kitapların listesi ve bu eserlerin tekrarlanma sayısı

\begin{tabular}{|c|c|c|c|c|c|}
\hline Eser Adı & $f$ & Eser $A d \imath$ & $f$ & Eser $A d \imath$ & $f$ \\
\hline 80 Günde Devr-i Âlem & 5 & Halime Kaptan & 3 & Perili Köşk & 1 \\
\hline Alaaddin'in Sihirli Lambası & 2 & Hansel ve Gratel & 4 & $\begin{array}{l}\text { Perşembeleri Çok } \\
\text { Severim }\end{array}$ & 1 \\
\hline Alice Harikalar Diyarında & 7 & Harry Potter & 1 & Peter Pan & 4 \\
\hline Allah'a Koşun & 1 & Heidi & 14 & Pinokyo & 18 \\
\hline Andersen Masalları & 3 & Hikâye Sofrası & 1 & Pollyanna & 16 \\
\hline Aşk ve Mai & 1 & İki Yıl Okul Tatili & 1 & Portakal & 1 \\
\hline Babaların Dönüşü & 1 & İnsan Ne ile Yaşar? & 1 & Rapunzel & 6 \\
\hline Ben Bir Başka Sen'im & 1 & İstanbul'un Fethi & 1 & Redkit & 1 \\
\hline Beyaz Diş & 1 & Kahve Tadında Hikâyeler & 1 & Robin Hood & 4 \\
\hline Beyaz Gemi & 3 & Karga Gagguk & 1 & Robinson Crouse & 1 \\
\hline Bilge Doktor & 1 & Kaşağ1 & 17 & Sadoko & 1 \\
\hline Bir Genç Kızın Gizli Defteri & 1 & $\begin{array}{l}\text { Kâşifin Güncesi: Yağmur } \\
\text { Yiyicilerin Kenti }\end{array}$ & 1 & Saftirik & 3 \\
\hline Bir Gül Ocağ & 1 & Keloğlan Masalları & 26 & Sak1z Sardunya & 1 \\
\hline Bir Küçük Osmancık Vardı & 8 & Kınalı Yapıncak & 1 & Sefiller & 3 \\
\hline Bir Yudum Sevgi & 1 & Kırmızı Başlıklı Kız & 16 & Sergüzeşt & 1 \\
\hline Bremen Mızıkacıları & 4 & Kitır ve Ailesi & 1 & Sevgi Masalı & 1 \\
\hline Charlie'nin Büyük Cam Asansörü & 1 & K1zilmaske & 4 & Sevgili Peygamberimiz & 1 \\
\hline Charlie'nin Çikolata Fabrikası & 2 & Kibritçi K1z & 4 & Simyacı & 1 \\
\hline Çalıkuşu & 2 & Kimlikçi Geldi Hanım & 1 & Siyah İnci & 3 \\
\hline Çanakkale & 1 & Kolsuz Bebek & 1 & Sobe & 1 \\
\hline Çatıdaki Gezegen & 1 & Köyden Gelen Kız & 1 & Sokaklardaki Ali & 1 \\
\hline Çirkin Ördek Yavrusu & 1 & Kurşun Asker & 1 & Sol Ayağım & 2 \\
\hline Çizgili Pijamalı Çocuk & 1 & Küçük Balıkçı & 1 & Suna'nın Serçeleri & 1 \\
\hline Çizmeli Kedi & 4 & Küçük Kemancı & 2 & Şeker Portakalı & 12 \\
\hline Çocuk Kalbi & 11 & Küçük Prens & 12 & Teksas & 3 \\
\hline Çocuklara En Güzel Öyküler & 1 & Külah & 1 & Tepegöz & 2 \\
\hline Dede Korkut Hikâyeleri & 4 & Külkedisi Sindirella & 11 & Tom Sawyer & 1 \\
\hline Dedemin Bakkalı & 1 & La Fontaine'den Masallar & 6 & Tommiks & 4 \\
\hline Define Adası & 6 & Lassie & 1 & Tonton & 1 \\
\hline Demiryolu Çocukları & 1 & Levent Serisi & 2 & Topuz & 1 \\
\hline Diyet & 1 & Martı & 1 & Türk Manileri & 1 \\
\hline Dokuzuncu Hariciye Koğuşu & 1 & Masal Çiftliği & 1 & Uçan Sınıf & 1 \\
\hline Don Kişot & 6 & Masal Sofrası & 1 & Uyuyan Güzel & 1 \\
\hline Dört Kardeştiler & 1 & Masallar Diyarı & 1 & Üç Silahşörler & 2 \\
\hline Dünya'nın Merkezine Seyahat & 4 & Memleket Hikâyeleri & 1 & Vatan Toprağ 1 & 1 \\
\hline Ezop Masalları & 1 & Menekşe Kokulu Hikâyeler & 1 & Yalancı Çoban & 1 \\
\hline Falaka & 2 & Monte Christo Kontu & 1 & Yalnız Efe & 4 \\
\hline Fareler ve İnsanlar & 1 & Nasreddin Hoca F1kraları & 9 & Yankılı Kayalar & 3 \\
\hline
\end{tabular}




$\begin{array}{lcllll}\text { Fareli Köyün Kavalcısı } & 1 & \text { Nene Hatun } & 2 & \text { Yaprak Dökümü } & 1 \\ \text { Forsa } & 2 & \text { Olmayan Ülke } & 1 & \text { Yaş On Yedi } & 1 \\ \text { Gizemli Harita Peşinde } & 1 & \text { Ökkeş Otoparkta } & 1 & \text { Yaşar Ne Yaşar Ne } & 1 \\ \text { Gizli Mabet } & 1 & \text { Ömer Seyfettin'den Seçmeler } & 4 & \text { Yeraltında Dünya Var } & 1 \\ \text { Gulliver'in Gezileri } & 2 & \text { Pamuk Prenses ve Yedi } & 16 & \text { Yılan Hikâyesi } & 1 \\ \text { Gulyabani } & 1 & \text { Parmak Çocuk } & 1 & \text { Yüksek Ökçeler } & 3 \\ \text { Gurbet Hikâyeleri } & 1 & \text { Parmak Uçları } & 1 & \text { Zagor } & 3 \\ \text { Gülyarası } & 1 & \text { Pembe İncili Kaftan } & 3 & & \\ \text { Hacivat ve Karagöz } & 1 & \text { Peri Masalları } & 1 & & \\ & & & & \end{array}$

Tablo 2'ye göre, 394 veliden 192'sinin toplamda 141 farklı çocuk kitabını okuduğu belirlenmiştir. Velilerin okuduğu kitaplara ve tekrarlanma sayısına göre en çok okunan kitaplar sırasıyla; Keloğlan Masalları (26), Pinokyo (18), Kaşağı (17), Kırmızı Başlıklı Kız (16), Pamuk Prenses ve Yedi Cüceler (16), Polyanna (16), Heidi (14), Şeker Portakalı (12), Küçük Prens (12), Çocuk Kalbi (11), Külkedisi Sindirella (11), Nasreddin Hoca Fıkraları (9), Bir Küçük Osmancık Vardı (8), Alice Harikalar Diyarında (7), Define Adası (6), Don Kişot (6), Rapunzel (6)'dir.

Tablo 3: Velilerin sadece bilgi sahibi olduğu çocuk kitapları ve tekrarlanma sayıları

\begin{tabular}{|c|c|c|c|c|c|}
\hline Eser $A d t$ & $f$ & Eser Adı & $f$ & Eser Adı & $f$ \\
\hline 101 Dalmaçyalı & 1 & Haritada Kaybolmak & 1 & Pembe İncili Kaftan & 2 \\
\hline 80 Günde Devr-i Alem & 1 & Harry Porter & 1 & Peter Pan & 3 \\
\hline Ağaç Sevgisi & 1 & Havaya Uçan At & 1 & Pinokyo & 14 \\
\hline Alice Harikalar Diyarında & 5 & Heidi & 13 & Pollyanna & 6 \\
\hline And & 1 & Hindistan Cevizi & 1 & Portakal Kokulu Masallar & 1 \\
\hline Andersen Masalları & 2 & Hint Masalları & 1 & Prenses Kalesi & 1 \\
\hline Anneannem ve Hayvanlar & 1 & Hünerli Hayvanlar & 1 & Rapunzel & 3 \\
\hline Ant & 1 & İçimdeki Müzik & 1 & Ressam Çocuk & 1 \\
\hline Arap Masalları & 1 & İnsan Ne ile Yaşar? & 1 & Robin Hood & 4 \\
\hline Aras'ın Kuşları & 1 & Kafadan Kontaklar & 1 & Rüzgâr & 1 \\
\hline Arasında Sarıkız & 1 & Kardeşim Benim & 1 & Saftirik & 6 \\
\hline Ay'a Yolculuk & 1 & Karlar Kraliçesi & 1 & Sakız Kızın Günleri & 1 \\
\hline Az Buçuk Teo & 1 & Kaşağ1 & 4 & Sakız Sardunya & 6 \\
\hline Az Gittik Uz Gittik & 2 & Kayıp Gül 2 & 1 & Sayısal Çocuk & 1 \\
\hline Babamın Gözleri Kedi Gözleri & 1 & Keloğlan Masalları & 9 & Sefiller & 2 \\
\hline Bacaksız Okulda & 1 & Kemanc1 & 1 & Seksen Günde Devr-i Âlem & 1 \\
\hline Balina Avcıları & 1 & Kırık F1skiye & 1 & Sergüzeşt & 1 \\
\hline Beyaz At & 1 & Kirmızı Balon & 1 & Sessiz Sakin & 1 \\
\hline Beyaz Diş & 3 & Kırmızı Başlıklı Kız & 7 & Sevdim Seni Matematik & 1 \\
\hline Beyaz Gemi & 3 & K1z Kulesi & 1 & Seyit Onbaşı & 1 \\
\hline Beyaz Yele & 1 & Kizil Sultan & 1 & Shrek & 1 \\
\hline Bir Küçük Osmancık Vardı & 4 & Kibritçi Kız & 3 & Sicak Ekmek & 1 \\
\hline Boğa Ferdinand & 1 & Kim Bu Yeni Çocuk? & 1 & Sinekli Bakkal & 2 \\
\hline Bunun Ad Aindel & 1 & Kip Kardeşler & 1 & Siyah İnci & 1 \\
\hline Buzlar Ülkesi & 1 & Köroğlu & 1 & Sokakta Tek Başına & 1 \\
\hline Ceylanlı Bahçe & 1 & Kraliçeyi Kurtarmak & 6 & Sol Ayağım & 3 \\
\hline Charlie'nin Çikolata Fabrikası & 8 & Kuklaci & 1 & Sonsuz Hayat & 1 \\
\hline Çanakkale & 1 & Kurbağa ile Fare & 1 & Sophie'nin Başına Gelenler & 1 \\
\hline Çirkin Ördek Yavrusu & 1 & Kurt ile Yedi Oğlak & 1 & Suna'nın Serçeleri & 1 \\
\hline Çizmeli Kedi & 2 & Küçük Balık & 1 & Süper Gazeteciler & 1 \\
\hline Çocuğunuza Sınır Koymayın! & 1 & Küçük Kemancı & 2 & Şehitler Tepesi & 1 \\
\hline Çocuk Kalbi & 9 & Küçük Prens & 17 & Şeker Portakalı & 3 \\
\hline Dede Korkut Hikâyeleri & 5 & Küçük Prenses & 1 & Şirin & 1 \\
\hline Dedemin Bakkalı & 1 & Külkedisi Sindirella & 4 & Tanrı Misafiri & 1 \\
\hline Define Adası & 1 & Küpeli & 1 & Tatil Rüyası & 1 \\
\hline Deli Dumrul & 1 & Kütük & 1 & Tom Sawyer & 2 \\
\hline Deniz K1z1 & 1 & La Fontaine Masalları & 3 & Uçan Sınıf & 1 \\
\hline Denizler Altında 20.000 Fersah & 2 & Lassie & 1 & Umut Sokağı Çocukları & 1 \\
\hline
\end{tabular}




\begin{tabular}{llllll} 
Domates Saçlı Kız & 1 & Levent Serisi & 4 & Üç Anadolu Efsanesi & 1 \\
Don Kişot & 6 & Lodos Yolcuları & 1 & Üç Silahşörler & 5 \\
Dondurmam Tılsım & 1 & Masal Adası & 1 & Üşütük Kızın Günlüğ̈ & 1 \\
Dört Kardeştiler & 1 & Masal Denizi & 1 & Vampirin Günlüğü & 1 \\
Endişe Ağacı & 1 & Mektup Arkadaşları & 1 & Vanilya Kokulu Mektuplar & 1 \\
Ezop Masalları & 3 & Menekşe Kokulu Hikâyeler & 1 & Yaban Kuğuları & 1 \\
Falaka & 2 & Momo & 1 & Yalnı Efe & 6 \\
Fareli Köyün Kavalcısı & 1 & Mutlu Aile & 1 & Yankılı Kayalar & 6 \\
Fatih Sultan Mehmet & 1 & Mutlu Prens & 1 & Yaşlı Adam ve Deniz & 1 \\
Gazete Fısıltıları & 1 & Mutluluğun Yolu & 1 & Yeşil Kiraz & 1 \\
Gizli Bahçe & 1 & Narnia Günlükleri & 1 & Yiğit Öğretmen & 1 \\
Gulliver'in Gezileri & 2 & Nasrettin Hoca Fıkraları & 1 & Yunan Masalları & 1 \\
Gül Ağacı Sokağı & 1 & Osmanlı Tarihi & 1 & Yurdumu Özledim & 1 \\
Gülibik & 1 & Oz Büyücüsü & 1 & Yusuf ile Züleyha & 1 \\
Göl Çocukları & 11 & Pamuk Prenses ve Yedi & 6 & & \\
Halime Kaptan & & Cüceler & & & \\
Hansel ve Gratel & 1 & Parmak Çocuk & 1 & & \\
\hline
\end{tabular}

Tablo 3'e göre, 394 veliden 163'ünün toplamda 162 farklı kitap hakkında bilgi sahibi olduğunu belirlenmiştir. Bulgulara göre velilerin en çok bildiği ya da duyduğu kitaplar sırasıyla; Küçük Prens (17), Pinokyo (14), Heidi (13), Göl Çocukları (11), Çocuk Kalbi (9), Keloğlan Masalları (9), Charlie'nin Çikolata Fabrikası (8), Kırmızı Başlıklı Kız (7), Kraliçeyi Kurtarmak (6), Pamuk Prenses ve Yedi Cüceler (6), Pollyanna (6), Saftirik (6), Sakız Sardunya (6), Yalnız Efe (6), Yankılı Kayalar (6)'dır.

Velilerin bir bölümünün okuduğu, bir bölümünün ise okumayıp hakkında bilgi sahibi olduğunu ifade ettiği 57 ortak kitap bulunmaktadır ve bu kitapların isimleri alfabetik sıraya göre; 80 Günde Devr-i Âlem, Alice Harikalar Diyarında, Andersen Masalları, Beyaz Diş, Beyaz Gemi, Bir Küçük Osmancık Vardı, Charlie'nin Çikolata Fabrikası, Çanakkale, Çirkin Ördek Yavrusu, Çizmeli Kedi, Çocuk Kalbi, Dede Korkut Hikayeleri, Dedemin Bakkalı, Define Adası, Don Kişot, Dört Kardeştiler, Ezop Masalları, Falaka, Fareli Köyün Kavalcısı, Gullıver'in Gezileri, Halime Kaptan, Hansel ve Gratel, Harry Porter, Heidi, İnsan Ne ile Yaşar?, Kaşağı, Keloğlan Masalları, Kırmızı Başlıklı Kız, Kibritçi Kız, Küçük Kemancı, Küçük Prens, Külkedisi Sindirella, La Fontaine’den Masallar, Lassie, Levent Serisi, Menekşe Kokulu Hikayeler, Nasreddin Hoca F1kraları, Pamuk Prenses ve Yedi Cüceler, Parmak Çocuk, Pembe İncili Kaftan, Peter Pan, Pinokyo, Pollyanna, Rapunzel, Robin Hood, Sakız Sardunya,Sefiller, Sergüzeşt, Siyah İnci, Sol Ayağım, Suna'nın Serçeleri, Şeker Portakalı, Tom Sawyer, Uçan Sınıf, Üç Silahşörler, Yalnız Efe, Yankılı Kayalar şeklindedir.

\section{Veliler ve Öğrencilerin Okudukları Çocuk Kitapları Arasındaki Benzerliğe İlişkin Bulgular}

Tablo 4: Öğrencilerin en son okuduğu kitaplar, yazarları ve tekrarlanma sayısı

\begin{tabular}{|c|c|c|c|c|c|}
\hline Eser $A d \imath$ & Yazar Adı & $f$ & Eser Adı & Yazar adı & $f$ \\
\hline 80 Günde Devr-i Âlem & Jules Verne & 1 & Halime Kaptan & Rifat Ilgaz & 1 \\
\hline Arşimet Zekai & Duran Çetin & 1 & İçimdeki Müzik & Sharon M. Drapen & 1 \\
\hline Âşık Veysel & Boş & 1 & İnci'nin Maceraları & Orhan Kemal & 1 \\
\hline Aya Yolculuk & Jules Verne & 1 & Küçük Prens & Antoine Exupery & 1 \\
\hline $\begin{array}{l}\text { Beacon Caddesi Kızları } \\
\text { (Yüreğimden Mektuplar) }\end{array}$ & Anne Bryant & 1 & Levent Serisi & Mustafa Orakçı & 3 \\
\hline Ben Bir Gürgen Dalıyım & Hasan Ali Toptaş & 1 & Masal Ormanı & Meltem Bilir Çimen & 1 \\
\hline Beyaz Diş & Jack London & 1 & Mezar Soyguncuları & Bilgin Adalı & 1 \\
\hline Beyaz Yele & Rene Guillet & 1 & Mezar Taşları Adası & Boş & 1 \\
\hline Beyaz Zambaklar Ülkesinde & Grigory Petrov & 1 & Momo & Michael Ende & 1 \\
\hline Bin Muhteşem Güneş & Halit Hüseyni & 2 & Osmanlı Tarihi Kitabı & Nezir Özger & 1 \\
\hline Bir Genç Kızın Gizli Defteri & İpek Ongun & 1 & Polyanna & Boș & 1 \\
\hline Bir Küçük Osmancık Vardı & Hasan Nail Canat & 1 & Sakız Sardunya & Elif Şafak & 1 \\
\hline Biricik Peygamberim & Boş & 1 & Serçekuş & Cahit Zarifoğlu & 1 \\
\hline Kar Taneleri & Sabiha Serin & 1 & Sharlock Holmes & Arthur C. Doyle & 1 \\
\hline Boş & Jules Verne & 1 & Sol Ayağım & Christy Brown & 2 \\
\hline Canoğlan & Boş & 1 & Sular Altında Bir Ülke & Yavuz Bahadıroğlu & 1 \\
\hline
\end{tabular}




\begin{tabular}{|c|c|c|c|c|c|}
\hline \multicolumn{2}{|c|}{ Charlie'nin Çikolata Fabrikası Road Dahl } & 1 & $\begin{array}{l}\text { Süper Gazeteciler: } \\
\text { Belalı Davetiye }\end{array}$ & Aytül Akal & 1 \\
\hline Çaylak Yazar İş Başında & Boş & 1 & Şeker Portakalı & $\begin{array}{l}\text { Josemauro de } \\
\text { Vasconceles }\end{array}$ & 2 \\
\hline Çitır Tavşan & Devrim Altay & 1 & Şeytanın Rüya Kapanı & Boş & 1 \\
\hline Don Kişot & Cervantes & 2 & Uçurtma Avcisı & Halit Hüseyni & 2 \\
\hline $\begin{array}{l}\text { Dünya'nın Merkezine } \\
\text { Yolculuk }\end{array}$ & Jules Verne & 1 & Uğultulu Tepeler & Boş & 1 \\
\hline Eyvah Kitap & Mine Soysal & 1 & Üşütük Kızın Günlüğü & Anna Cammy & 1 \\
\hline Fareler ve İnsanlar & John Steinback & 1 & $\begin{array}{l}\text { Yüzyılın Bomba } \\
\text { Haberi }\end{array}$ & Sophie Dieuaide & 1 \\
\hline Gün Gelir & Boș & 1 & & & \\
\hline
\end{tabular}

Örneklemdeki 80 öğrenciden sadece 54'ü en son okunulan eser ve yazarı sorusuna cevap vermiştir. Tablo 4'e göre, 54 öğrenci 46 farklı eser ismi belirtmiştir. Bu eserlerden en çok okunanlar, yazarları ve tekrarlanma sayısına göre; Mustafa Orakçı'nın Levent Serisi eseri 3 kez, Halit Hüseyni’nin Bin Muhteşem Güneş eseri 2, Cervantes'in Don Kişot'u 2, Christy Brown'un Sol Ayağım eseri 2, Vasconcales'un Şeker Portakalı 2 ve Halit Hüseyni'nin Uçurtma Avcısı adlı eseri 2 kez tekrar edilmiştir. Bu sıralamaya bakıldığında en çok okunan yazarın Halit Hüseyni (4) olduğu görülmektedir.

Tablo 5: Veli ve öğrencilerin okudukları çocuk kitapları

\begin{tabular}{lll}
\hline \multicolumn{2}{c}{ Çocuk Kitapları } \\
\hline 1. 80 Günde Devr-i Âlem & 8. Fareler ve İnsanlar \\
2. Beyaz Diş & 9. Halime Kaptan \\
3. Bir Genç Kızın Gizli Defteri & 10. Küçük Prens \\
4. Bir Küçük Osmancık Vardı & 11. Levent Serisi \\
5. Charlie'nin Çikolata Fabrikası & 12. Pollyanna \\
6. Don Kişot & 13. Sakız Sardunya \\
7. Dünya'nın Merkezine Yolculuk & 14. Sol Ayağım \\
& 15. Şeker Portakalı \\
\hline
\end{tabular}

Tablo 5'e göre, çocuk kitabı okumuş olan velilerin ve en son okuduğu eseri belirten öğrencilerin okuduğu 15 ortak eser bulunmaktadır. Bu eserlerin içerisinde Türk edebiyatından ve dünya edebiyatından eserlerin olması dikkat çekmektedir.

Tablo 6: Velilerin bilgi sahibi olduğu öğrencisinin ise okuduğu eserler
1. Don Kişot
2. Üşütük Kızın Günlüğü

Çocuk Kitapları

Örneklemdeki velilerin bilgi sahibi olduğu öğrencilerinin ise okumuş olduğu 2 farklı eser tespit edilmiştir. Bunlar Don Kişot ve Üşütük Kızın Günlügü̈'dür. Bu bulgu örneklemdeki veliler ile öğrencilerinin okuduğu ortak kitabın olmadığını, sadece çocuklarının okuduğu 2 kitap hakkında velilerinin bilgi sahibi olduğunu göstermektedir.

\section{Sonuç ve Tartışma}

Öğrencilerin okuma alışkanlığı kazanma sürecinde ailede ve yakın çevrelerinde kitap okunmasına dair örnekler görmeleri; anne, baba veya öğretmenlerini model alabilmeleri önemlidir. Bu doğrultuda, velilerin bilgi sahibi olduğu ve hem öğrencilerin hem de velilerin okuduğu çocuk kitaplarının belirlenmesini amaçlayan araştırmada şu sonuçlara ulaşılmıştır:

Velilerin en çok okuduğu çocuk kitaplarının sırasıyla; Keloğlan Masalları, Pinokyo, Kaşağı, Kırmızı Başlıklı Kız, Pamuk Prenses ve Yedi Cüceler, Polyanna, Heidi, Şeker Portakalı, Küçük Prens, Çocuk Kalbi, Külkedisi Sindirella, Nasreddin Hoca Fıkraları, Bir Küçük Osmancık Vardı, Alice Harikalar Diyarında, Define Adası, Don Kişot ve Rapunzel olduğu görülmüştür. Velilerin okumadığı fakat bilgi sahibi olduğu kitaplar ise sırasıyla; Küçük Prens, Pinokyo, Heidi, Göl Çocukları, Çocuk Kalbi, Keloğlan Masalları, Charlie'nin Çikolata Fabrikası, Kırmızı Başlıklı Kız, Kraliçeyi Kurtarmak, Pamuk Prenses ve Yedi Cüceler, Pollyanna, Saftirik, Sakız Sardunya, Yalnız Efe ve Yankılı Kayalar olduğu sonucuna ulaşılmıştır.

Velilerin bir bölümünün okuduğu ancak bir bölümünün okumayıp hakkında bilgi sahibi olduğunu ifade ettiği 57 farklı çocuk kitabının olduğu da ulaşılan sonuçlar arasındadır. Bu kitaplar alfabetik sırasıyla; 80 Günde Devr-i 
Âlem, Alice Harikalar Diyarında, Andersen Masalları, Beyaz Diş, Beyaz Gemi, Bir Küçük Osmancık Vardı, Charlie'nin Çikolata Fabrikası, Çanakkale, Çirkin Ördek Yavrusu, Çizmeli Kedi, Çocuk Kalbi, Dede Korkut Hikâyeleri, Dedemin Bakkalı, Define Adası, Don Kişot, Dört Kardeştiler, Ezop Masalları, Falaka, Fareli Köyün Kavalcısı, Gullıver'in Gezileri, Halime Kaptan, Hansel ve Gratel, Harry Porter, Heidi, İnsan Ne ile Yaşar?, Kaşağı, Keloğlan Masalları, Kırmızı Başlıkıı Kız, Kibritçi Kız, Küçük Kemancı, Küçük Prens, Külkedisi Sindirella, La Fontaine'den Masallar, Lassie, Levent Serisi, Menekşe Kokulu Hikayeler, Nasreddin Hoca Fıkraları, Pamuk Prenses ve Yedi Cüceler, Parmak Çocuk, Pembe İncili Kaftan, Peter Pan, Pinokyo, Pollyanna, Rapunzel, Robin Hood, Sakız Sradunya,Sefiller, Sergüzeşt, Siyah İnci, Sol Ayağım, Suna'nın Serçeleri, Şeker Portakalı, Tom Sawyer, Uçan Sınıf, Üç Silahşörler, Yalnız Efe ve Yankılı Kayalar şeklindedir. Velilerin okuduğu ya da okumayıp bilgi sahibi olduğu çocuk kitaplarının varlığına dair bulgu ile Suna'nın (2006) araştırmasında ulaşılan annebabanın kitap okuduğunu gören veya onlardan hediye olarak kitap alan çocukların okuma alışkanlığının daha yüksek olduğuna dair sonuçlar örtüşmektedir.

Öğrencilerin en son okuduğu ve en fazla tercih edilen kitaplar şu şekildedir: Levent Serisi, Bin Muhteşem Güneş, Don Kişot, Sol Ayağım, Şeker Portakalı ve Uçurtma Avcısı'dır. Bu sıralamaya göre öğrencilerin en çok tercih ettiği yazar Halit Hüseyni'dir. Arııı'nın (2005) araştırmasında ortaokul öğrencilerinin çoğunlukla macera içerikli kitapları sevdiğine dair bulgular ile araştırmanın sonuçları birbirini desteklemektedir. Erdemir ve Bayram'ın (2007) ortaokul öğrencilerinin okuduğu kitaplarla ilgili çalışmalarındaki tespit edilen eserlerle burada belirlenen (Falaka, Keloğlan, Don Kişot, Pollyanna, Fareler ve İnsanlar gibi) kitaplar arasında benzerlikler bulunmaktadır.

Hem velinin hem de öğrencisinin okuduğu ortak eser tespit edilememiştir. Bununla birlikte velinin bilgi sahibi olduğu öğrencisinin ise en son okuduğu iki eser tespit edilmiştir. Bunlar Don Kişot ve Üşütük Kızın Günlüğü'dür. Veliler ve diğer öğrencilerin okuduğu kitaplar içerisinde aynı / ortak olan 15 farklı eser tespit edilmiştir. Bu eserler; 80 Günde Devr-i Âlem, Beyaz Diş, Bir Genç Kızın Gizli Defteri, Bir Küçük Osmancık Vardı, Charlie'nin Çikolata Fabrikası, Don Kişot, Dünya'nın Merkezine Yolculuk, Fareler ve İnsanlar, Halime Kaptan, Küçük Prens, Levent Serisi, Pollyanna, Sakız Sardunya, Sol Ayağım ve Şeker Portakalı şeklindedir. Bu sonuç, velilerin çocuklarının okuyacağı kitapları önceden okuyup daha sonra çocuklarına tavsiye etme veya birlikte kitap okuma gibi alışkanlıklara sahip olmadığı şeklinde açıklanabilir. Balcı'nın (2009) ortaokul öğrencilerinin okuma alışkanlığı üzerine yaptığ 1 araştırmada, öğrencilerin okuma konusundaki en büyük teşvik kaynağının aileleri olduğu, yine ailelerin önemli bir kısmının çocuklarına kitap satın alarak bunu gerçekleştirdiğine dair tespitler ile araştırmada ulaşılan veliler ile öğrencilerin okudukları kitapların benzerliğine dair sonuçlar kısmen birbirini desteklemektedir.

\section{Öneriler}

Ortaokul öğrencilerinin ve velilerinin okudukları eserlere ilişkin sonuçlardan hareketle aşağıdaki önerilerde bulunulabilir:

Millı̂ Eğitim Bakanlığı’nın okullara çocuk edebiyatının tanınmış yazarlarını, çizerlerini götürmesi; böylece öğrenci ve velilerle buluşmalarını sağlamasına dair bir kampanya başlatabilir.

Yetişkinlere ve çocuklara okuma alışkanlığı kazandırmak, yetişkinlerde ve çocuklarda çocuk edebiyatına yönelik farkındalık oluşturmak için farklı çocuk edebiyatı yazarlarının da yer aldığı televizyon ya da internete yönelik kamu spotları / reklamlar hazırlatılabilir.

Çocuğun çocuk edebiyatına ve türlerine olan sevgisini artırmak, çocukta çocuk edebiyatı eserinin kendisini de okuma isteği oluşturmak adına çocuk radyosu veya internet üzerinden okul radyosu oluşturulabilir. Okul radyolarında çocuklara da bu eserlerin seslendirilmesiyle ilgili görevler verilebilir. Böylelikle öğrencilerin çocuk edebiyatına ve okumaya olan ilgisi artırılabilir.

Ailelerin çocuklarının okuyacağı kitapları önceden okuması veya birlikte okumasının ne kadar önemli olduğu hatırlatılmalıdır. Bunu sağlamak için velilere okuma görevleri verilebilir.

Velilerin çocuk kitapları konusunda bilgilendirilmesi için veli toplantılarında veya EBA üzerinden tanıtımlar yapılabilir. Bu tanıtımlarda çocuk kitapları yaşa, içeriğe ve diğer özelliklere göre gruplandırılıp velilerin çocuğu için en uygun olan eseri seçmesi kolaylaştırılabilir.

\section{Kaynakça}

Aksoy, E. (2014). İlköğretim öğrencilerinin okuma alışkanllğına ilişskin veli, öğretmen ve öğrenci görüşleri. Yayınlanmamış yüksek lisans tezi. Abant İzzet Baysal Üniversitesi Eğitim Bilimleri Enstitüsü İlköğretim Anabilim Dalı Sınıf Öğretmenliği Bilim Dalı, Bolu. 
Alver, B. (2005). Psikolojik danışma ve rehberlik eğitimi alan öğrencilerinin empatik beceri ve karar verme stratejilerinin çeşitli değişkenlere göre incelenmesi. Muğla Üniversitesi Sosyal Bilimler Enstitüsü Dergisi, 14, 19-34.

Arıc1, A. F. (2005). İlköğretim ikinci kademe öğrencilerinin okuma durumları (Beceri, ilgi, alışkanlık, ĕgilim). Yayınlanmamış doktora tezi. Atatürk Üniversitesi Sosyal Bilimler Enstitüsü Türkçe Eğitimi Ana Bilim Dal1, Erzurum.

Balc1, A. (2009). İlköğretim 8. sınıf öğrencilerinin okuma alışkanlık ve ilgileri üzerine bir araştırma. Yayınlanmamış doktora tezi. Gazi Üniversitesi Eğitim Bilimleri Enstitüsü Türkçe Eğitimi Ana Bilim Dalı, Ankara.

Bayram, Y. ve Erdemir A. (2007). Amasya'daki ilköğretim 6, 7 ve 8.sınıf öğrencilerinin okuma düzeyleri ve okuma eğilimleri. I. Amasya Araştırmaları (2. Kitap) içinde (s.1175-1200), Amasya: Amasya Valiliği Yayınları.

Bekar, Ü. (2005). Illköğretim beşinci sınıf ögrencilerinin okuma alışkanlı̆̆ kazanmalarında ailenin rolü (Kastamonu ili örneği). Yayınlanmamış yüksek lisans tezi. Gazi Üniversitesi Eğitim Bilimleri Enstitüsü Sınıf Öğretmenliği Bilim Dalı, Ankara.

Gökşen, E. N. (1980). Örnekleriyle çocuk edebiyatımız. İstanbul: Remzi Kitabevi.

Gürler, Ü. (1999). Çocuk kitapları ve anne babaların tutumları üzerine bir inceleme. Yayınlanmamış yüksek lisans tezi. Hacettepe Üniversitesi Sosyal Bilimler Enstitüsü, Ankara.

Huck, C. S. (1976). Children's literature in the elementary school. (3rd Edition). New York: Holt, Rinehart and Winston.

Şahin, A. (2007). Çocuk ve çocukluk. (Ö. Yılar, L. Turan (Ed.), Eğitim fakülteleri için çocuk edebiyatı içinde (s.7). Ankara: Pegem Akademi.

Şahin, E. Y., Çelik, G., ve Çelik, B. (2012). Anne babaların çocuk edebiyatı kavramına ilişkin görüşleri (Çanakkale örneği). Çanakkale Araştırmaları Türk Yıllı̆̆gl, 10(12), 109-125.

Savaş, B. (2006). Okuma eğitimi ve çocuklarda dil gelişimi. İstanbul: Alfa Yayınları.

Sever, S. (2007). Çocuk ve edebiyat. Ankara: Kök Yayıncılık.

Suna, Ç. (2006). Ilköğretim öğrencilerinin okuma ilgi ve alışkanlıklarının analitik olarak incelenmesi ve değerlendirilmesi. Yayımlanmamış yüksek lisans tezi. Anadolu Üniversitesi Sosyal Bilimler Enstitüsü, Eskişehir.

Şirin, M. R. (2000). 99 soruda çocuk edebiyatı. İstanbul: Çocuk Vakfı.

Şirin, M. R. (2007). Çocuk edebiyatına eleştirel bir bakış. Ankara: Kök Yayıncılık.

Yalçın, A., ve Aytaş, G. (2008). Çocuk edebiyatı. (4.Baskı). Ankara: Akçağ Yay.

Yavuzer, H. (2012). Doğum öncesinden ergenlik sonuna çocuk psikolojisi. İstanbul: Remzi Kitabevi.

Yıldırım, A. ve Şimşek, H. (2011). Sosyal bilimlerde araştırma yöntemleri. (8. baskı). Ankara: Seçkin Yayınları.

\section{Extended Abstract}

It can be said that reading and acquiring reading habit is important in human socialization, universalization, and development through establishing civilizations. The children raised in houses in which there are people reading books, will possibly have advanced reading skills. Parents should read books to their child, take him or her to the library, and give him or her books as a gift. If parents wish for a child who practices reading, they should be aware of the book types that are convenient for the age, level, and interest of the child. The children need a mentor such as parents at home or a teacher at school who can motive the child pleasefully. That is how a child maintains a positive attitude towards reading. Children want to understand and to be understood. They are quite important for us and they are improving dynamically. Their physical and mental development process is invaluable and if their innocence is desired to be preserved, parents should value their child. Therefore, the foundations of love for reading and reading habits are laid in preschool. Developed during the school year. Reading is very important for both individual development and social progress. 
Therefore, children should be given the habit of reading. Based on this situation the fail in acquiring reading habit beginning from the elementary ages is a problem need to be solved. Families, as well as educational activities and teachers, have many responsibilities and effects in acquiring the habit of reading. Therefore, school, teacher and family factors should be taken into consideration while developing reading habits. Based on these reasons, it was aimed to determine the literary works that secondary school students and parents read. Depending on this purpose, it was also important to determine whether there is a similarity between the works read by the students and parents. In the study, a qualitative research method was used. The universe of the study, which was conducted in the spring semester of 2017-2018 academic year, consists of parents of 5th, 6th, 7th and 8th grade students studying in Giresun province. The sample of the study was composed of Gedikkaya Secondary School and Çavuşlu Secondary School in Giresun city. The students ( $n=80)$ of Çavuşlu Middle School were also included in the study in terms of easy accessibility in order to reveal the similarities and differences between their works. In order to reveal the similarities and differences between parents 'literary works and students' literary works as a data collection tool in the research, The Parent Interview Form for Children's Literature and Student Interview Form for Reading Habits were used. Interview forms were delivered directly to the students and parents in the sample and collected in the same way. At the end of the study, it was determined that the parents read the Keloğlan Tales mostly and the students read the books Levent Series. In addition, it was concluded that most of the parents did not read any of the works of children's literature, but there were 15 common books between the children's literature works of parents and students. 